\title{
Hubungan Teman Sebaya dengan Perilaku Penggunaan Rokok Elektrik di Kalangan Mahasiswa
}

\author{
Peer Relationship with E-Cigarette Use Behavior among Students
}

\author{
Karmelia Nova Diana ${ }^{1 *}$, Maulidya Digandiana ${ }^{1}$, RR. Anis Illahi $^{1}$, Indisa \\ Titaniea Ishal ${ }^{1}$, Siti Mariam ${ }^{1}$, Sri Sunarti ${ }^{1}$
}

\author{
${ }^{1}$ Program Studi Kesehatan Masyarakat, Fakultas Ilmu Kesehatan dan Farmasi \\ Universitas Muhammadiyah Kalimantan Timur, Samarinda, Indonesia \\ *Korespondensi penulis: novamelia98@gmail.com
}

Penyerahan: 26-08-2020, Perbaikan: 08-09-2020, Diterima: 25-09-2020

\begin{abstract}
Smoking is a behavior that involves the process of burning tobacco, which will be smoked. Other factors that influence smoking behavior include internal factors and external factors such as peers. The purpose of this study was to analyze the relationship of peers with the behavior of using electric cigarettes among UMKT S1 Public Health students. This study used a cross-sectional research design. The population in this study are students in S1 UMKT Public Health, with many respondents around 214 people and using stratified random sampling techniques to determine the number of respondents. In this independent variable is the behavior of using electric cigarettes, while the dependent variable is peers. For this research instrument using the Google form as a questionnaire. The results of the questionnaire will be analyzed with the chi-square test. The results obtained in this study are that there is a significant relationship between using electric cigarettes with peers ( $p$-value $<0.001$ ).
\end{abstract}

Keywords: Peers, Smoking Behaviour, E-Cigarette User, E-Cigarette.

\begin{abstract}
ABSTRAK
Merokok ialah perilaku yang melibatkan proses membakar tembakau yang kemudian akan dihisap asapnya. Faktor lain yang mempengaruhi perilaku merokok diantaranya seperti faktor dalam diri dan faktor dari luar diri seperti teman sebaya. Tujuan dari penelitian ini ialah untuk menganalisis hubungan teman sebaya dengan perilaku penggunaan rokok elektrik di kalangan mahasiswa S1 Kesehatan Masyarakat UMKT. Penelitian ini menggunakan desain penelitian cross sectional dengan populasi yang ada di penelitian ini adalah mahasiswa/i di S1 Kesehatan Masyarakat UMKT dengan jumlah responden sekitar 214 orang, serta menggunakan teknik stratified random sampling untuk menentukan jumlah respondennya. Pada variabel independen ini adalah perilaku penggunaan rokok elektrik, sementara variabel dependennya adalah teman sebaya. Untuk instrumen penelitian ini menggunakan google form sebagai kuesionernya. Hasil kuesioner tersebut akan di analisis dengan uji chi square. Hasil yang didapatkan pada penelitian ini adalah ada hubungan yang signifikan antara perilaku penggunaan rokok elektrik dengan teman sebaya ( $p$-value $<0.001$ ).
\end{abstract}

Kata kunci: Teman sebaya, Perilaku Merokok, Penggunaan rokok elektrik, Rokok elektrik. 


\section{PENDAHULUAN}

Di Indonesia pada tahun 2018 untuk proporsi rokok elektrik yang dihisap penduduk umur kurang dari 10 tahun sebanyak $2.8 \%$, pengguna rokok elektrik terbanyak terdapat pada kelompok usia 10 sampai usia 14 tahun sebesar $10.6 \%$, kelompok usia 15 sampai usia 19 tahun sebesar $10.5 \%$, dan kelompok usia 20 sampai usia 24 tahun sebesar $7 \%$ (Riskesdas, 2018).

Berdasarkan data dari House and Commoms Research Library, diketahui bahwa rentan usia remaja mengkonsumsi rokok elektrik atau vapor ialah remaja tengah (15-18 tahun) yaitu sebesar $43.3 \%$. Jika dirinci lebih lanjut maka ada sebanyak $33 \%$ pengguna rokok elektrik ini ialah untuk yang berniat berhenti merokok secara tradisional, sebanyak $11.5 \%$ mantan perokok, sebanyak $10 \%$ kalangan usia muda (11-18 tahun) yang mencoba rokok elektrik (House and Commons Research Library, 2019).

Munculnya rasa ketertarikan terhadap adanya rokok elektrik di indonesia pada tahun 2010 mencapai 10,9\%. Dimana sebanyak 16,8\% laki-laki menggunakan rokok elektrik ialah laki-laki yang mencapai 16,8\%. Sedangkan pada usia 15-24 tahun minat rokok elektrik lebih besar dibandingkan dengan usia 25-44 tahun yaitu $14,4 \%$ dengan $12,4 \%$ (Damayanti,2016).

Provinsi di Indonesia dengan banyaknya proporsi rokok elektrik yang dihisap oleh penduduk pada umur 10 tahun terbanyak antara lain ialah provinsi Daerah Istimewa Yogyakarta sebesar 7.4\%, Kalimantan Timur sebesar 6\%, DKI Jakarta sebesar $5.9 \%$, Kalimantan Selatan sebesar $4.9 \%$, dan provinsi Bali Sebesar 4.2\% (Media Indonesia, 2019). Berdasarkan data dari PKM Juanda didapatkan remaja (16-20 tahun) yang menggunakan rokok, yaitu sebanyak $23.2 \%$ atau 41 orang laki-laki dan sebanyak $4 \%$ atau 2 orang perempuan. Kemudian diketahui bahwa teman sebaya merupakan faktor yang paling mempengaruhi remaja dalam mengkonsumsi rokok elektrik (vape). Teman sebaya dapat juga mempengaruhi remaja dalam menggunakan rokok elektrik. Selain sebagai bentuk informasi, teman sebaya yang menggunakan rokok elektrik akan lebih mudah mempengaruhi perilaku merokok pada remaja. Berdasarkan hasil studi pendahuluan dengan melakukan pendataan kepada mahasiswa Program Studi S1 Kesehatan Masyarakat Universitas Muhamadiyah Kalimantan Timur tahun 2020, didapatkan bahwa terdapat sebanyak $47.7 \%$ atau 21 orang yang merupakan mahasiswa pengguna rokok tembakau dan sebanyak $52.3 \%$ atau 23 orang yang merupakan pengguna rokok elektrik.

Berdasarkan latar belakang diatas, pengguna rokok tembakau dan rokok elektrik pada remaja terutama dikalangan mahasiswa masih tinggi. Oleh karena itu, studi ini bertujuan untuk menganalisis hubungan teman sebaya dengan perilaku penggunaan rokok elektrik dikalangan mahasiswa Kesehatan Masyarakat Universitas Muhammadiyah Kalimantan Timur.

\section{METODE}

Penelitian ini akan menggunakan desain penelitian, yaitu cross sectional. Desain ini digunakan untuk mengetahui hubungan teman sebaya dengan perilaku penggunaan rokok elektrik di kalangan mahasiswa. Cross sectional merupakan desain penelian suatu kejadian yang dimana peneliti tersebut meneliti dalam satu waktu sekaligus pada saat yang bersamaan. Untuk analisis 
menggunakan uji statatistik Chi Square. Populasi ialah suatu wilayah generalisasi yang terdiri atas obyek atau subyek yang mempunyai kualitas dan karakteristik tertentu yang ditetapkan oleh peneliti untuk dipelajari dan kemudian ditarik kesimpulannya (Sugiyono, 2018). Populasi dalam penelitian ini yaitu mahasiswa-mahasiswi yang ada di kampus perguruan tinggi yaitu UMKT sebanyak 462 mahasiswa. Populasi yang akan diteliti dalam penelitian ini adalah mahasiswa semester 2,4 dan 6 yang ada di kampus UMKT (Universitas Muhammadiyah Kalimantan Timur). Sampel merupakan salah satu bagian dari jumah dan karakteristik yang mempunyai populasi tersebut (Dharma, 2011).

Sampel didapat dari mahasiswa dari semester 2, 4, dan 6 di UMKT dengan teknik pengambilan sampel menggunakan teknik stratified random sampling, yaitu cara pengambilan sampel dengan terlebih dahulu membuat penggolongan atau pengelompokkan populasi menurut karakteristik tertentu (Tika, 2006).

Pada penelitian ini akan menggunakan kuesioner sebagai alat pengambilan data. Kuesioner merupakan alat yang biasanya digunakan peneliti untuk mengambil sebuah data. Kuesioner yang akan digunakan ada 2 jenis. Kuesioner yang pertama untuk mengukur perilaku penggunaan rokok elektrik pada mahasiswa dan yang kedua untuk mengukur teman sebaya pada mahasiswa.

\section{HASIL}

Berdasarkan tabel 1 diatas, responden terbanyak dengan jenis kelamin perempuan yang berjumlah 156 responden dengan persentase sebesar $72.9 \%$ dan responden lakilaki berjumlah 58 orang dengan persentase $27.1 \%$. Usia responden dengan jumlah tertinggi ialah usia 19 tahun dengan persentase sebesar $44.9 \%$ dan jumlah terendah pada usia 17 dan 23 tahun sebesar $0.5 \%$. Tentang perilaku, diketahui bahwa dari 214 responden didapatkan responden yang menjawab tidak sebanyak 196 responden dengan persentase sebesar $91.6 \%$ sedangkan yang menjawab ya sebanyak 18 responden dengan persentase sebesar $8.4 \%$. Variabel dependen dalam penelitian ini adalah teman sebaya yang didapatkan responden yang berpengaruh sebanyak 180 responden dengan persentase sebesar $84.1 \%$ sedangkan yang tidak berpengaruh sebanyak 34 responden dengan persentase sebesar $15.9 \%$.

Tabel 1. Distribusi Frekuensi Karakteristik Responden

\begin{tabular}{lcc}
\hline \multicolumn{1}{c}{ Variabel } & Frekuensi (n) & Persentase (\%) \\
\hline Jenis Kelamin & 156 & 72.9 \\
Perempuan & 58 & 27.1 \\
Laki-laki & & \\
Usia (tahun) & 126 & 58.8 \\
$<20$ & 88 & 41.2 \\
$\geq 20$ & & \\
Perilaku Penggunaan & 18 & 8.4 \\
Rokok Elektrik & 196 & 91.6 \\
Ya & & \\
Tidak & & \\
Teman Sebaya & & \\
\hline
\end{tabular}




\begin{tabular}{lcc}
\hline \multicolumn{1}{c}{ Variabel } & Frekuensi (n) & Persentase (\%) \\
\hline Berpengaruh & 180 & 84.1 \\
Tidak Berpengaruh & 34 & 15.9 \\
\hline
\end{tabular}

Tabel 2. Hubungan Antara Perilaku Pengguna Rokok Elektrik dengan Teman sebaya

\begin{tabular}{lcrl}
\hline \multirow{2}{*}{$\begin{array}{c}\text { Perilaku } \\
\text { Penggunaan } \\
\text { Rokok Elektrik }\end{array}$} & \multicolumn{2}{c}{ Teman Sebaya } & P-value \\
\cline { 2 - 3 } & Berpengaruh & $\begin{array}{c}\text { Tidak } \\
\text { Berpengaruh }\end{array}$ & \\
\hline Ya & $13(72.2 \%)$ & $5(27.8 \%)$ & $<0.001$ \\
Tidak & $21(10.7 \% \%)$ & $175(89.3 \%)$ & \\
\hline
\end{tabular}

Dari tabel 2, diketahui dari 18 responden yang memiliki jawaban ya perilaku penggunaan rokok elektrik sebanyak 13 responden (72.2\%) diantaranya teman sebaya, sedangkan 196 responden yang memiliki jawaban tidak perilaku penggunaan rokok elektrik, 21 responden $(10.7 \%)$ diantaranya teman sebaya.

Untuk menguji hubungan secara statistik, maka harus melakukan uji chi-square dengan hasil yang didapatkan $\propto=0.05$ diperoleh bahwa nilai $\mathrm{p}<0.001$, artinya terdapat hubungan antara perilaku penggunaan rokok elektrik dengan teman sebaya.

\section{PEMBAHASAN}

Berdasarkan hasil analisis data univariat mengenai frekuensi perilaku penggunaan rokok elektrik pada mahasiswa UMKT bahwa terdapat sebanyak 18 (8.4\%) mahasiswa yang menjawab ya. Berdasarkan hasil analisis data univariat mengenai frekuensi teman sebaya, diketahui bahwa teman sebaya yang paling banyak dijawab oleh responden ialah berpengaruh $(84.1 \%)$ dan yang tidak berpengaruh saat bersama teman sebaya (15.9\%). Hubungan antara perilaku penggunaan rokok elektrik dengan teman sebaya. Berdasarkan tabel 5 tentang perilaku penggunaan rokok elektrik, didapatkan responden yang memiliki jawaban tidak yang menggunakan rokok elektrik sebanyak 196 responden, jumlah ini lebih banyak dari pada responden dengan jawaban ya menggunakan rokok elektrik.

Penggunaan rokok elektrik diduga berhubungan erat dengan teman sebaya. Hal ini terbukti pada analisa ditabel 5 dimana menunjukkan adanya hubungan yang bermakna antara menggunakan rokok elektrik dengan bersama teman sebaya pada responden dengan nilai $\mathrm{p}<0.001$. Sebanyak 18 responden yang memiliki jawaban ya terdapat 13 responden $(72.2 \%)$ yang pernah menggunakan rokok elektrik saat bersama teman sebaya. Sedangkan dari 196 responden yang memiliki jawaban tidak sebanyak 21 responden $(10.7 \%)$ diantaranya pernah menggunakan rokok elektrik saat bersama teman sebaya.

Berdasarkan data yang telah diselesaikan dapat ditarik kesimpulan bahwa mahasiswa yang memiliki jawaban ya menggunakan rokok elektrik berpeluang untuk pernah menggunakan rokok elektrik saat bersama teman sebaya dibandingkan mahasiswa yang memiiki jawaban tidak.

\section{KESIMPULAN}

Terdapat hubungan antara perilaku penggunaan rokok elektrik dengan teman sebaya di mahasiswa S1 
Kesehatan Masyarakat Universitas Muhammadiyah Kalimantan Timur.

\section{SARAN}

Universitas

Muhammadiyah

Kalimantan Timur dapat membentuk kebijakan dengan adanya larangan penggunaan rokok elektrik di wilayah kampus (Kawasan Bebas Asap Rokok), serta membuat berbagai macam media terkait bahaya penggunaan rokok elektrik. Penelitian selanjutnya dapat mencakup responden yang lebih luas, menggunakan variabel dependen dan independen yang lebih banyak lagi serta dapat menggunakan analisis multivariat untuk melihat lebih banyak faktorfaktor yang dapat mempengaruhi.

\section{DAFTAR PUSTAKA}

Adiyofa, I., \& Aulia, P. (2019). Kontribusi Konformitas Teman Sebaya Terhadap Perilaku Merokok Pada Remaja Awal Disekolah X. Jurnal Riset Psikologi, 2019(4).

Agina, D. T., Pertiwi, F. D., \& Avianty, I. (2019). FaktorFaktor Yang Berhubungan Dengan Perilaku Penggunaan Vapor di Kalangan Siswa Sekolah Menengah Kejuruan Bina Sejahtera 2 Kota Bogor. PROMOTOR, 2(2), 101111.

Akilasari, Y., Risyak, B., \& Sabdaningtyas, L. (2015). Faktor Keluarga, Sekolah dan Teman Sebaya Pendukung Kemampuan Sosial Anak Usia Dini. Jurnal Pendidikan Anak, 1(5).

Alamsyah, I. E. (2018). Jumlah Perokok di Indonesia Masih Tinggi. Republika.co.id. Retrieved From https://www.republika.co.id/ber ita/gaya-hidup/info- sehat/18/06/05/puhdd34jumlah perokokdi-indonesia-masihtinggi

Montreuil, A., MacDonald, M., Asbridge, M., Wild, T. C., Hammond, D., Manske, S., \& Rutherford, E. (2017). Prevalence and correlates of electronic cigarette use among Canadian students: crosssectional findings from the 2014/15 Canadian Student Tobacco, Alcohol and Drugs Survey. CMAJ open, 5(2), E460. Artanti, K. D., Widati, S., Martini, S., Megatsari, H., \& Nugroho, P. A. (2017). Deskripsi Perilaku Merokok E-Cigarette dan Konvensional pada Anak Sekolah Di Kota Surabaya. In Proceeding 4th Indonesian Conference on Tobacco or Health 2017.

BPOM. (2015). Info POM Bahaya Rokok Elektronik. Jakarta: Vol. 16 No. 5

Burlian, Paisol. (2016). Patologi Sosial. Jakarta: Bumi Aksara

Bushore, Crish \& Barbara Pizacani. 2015. E-cigarettes: a reviews of the literature. Alaska: Departemen Of Health and Sosial Service

Center For Disease Control and Prevention (CDC). Atlanta: Center For Disease Control and Prevention (CDC). 2017. Available at: https://www.cdc.gov/tobacco/d ata-statistics/fact-sheets/youthdata/tobacco-use/index.htm

Agina, D. T., Pertiwi, F. D., \& Avianty, I. (2019). FaktorFaktor Yang Berhubungan Dengan Perilaku Penggunaan Vapor di Kalangan Siswa Sekolah Menengah Kejuruan Bina Sejahtera 2 Kota Bogor. PROMOTOR, 2(2), 101111. 
Dharma, K. K. (2011). Metodologi penelitian

keperawatan. Jakarta: Trans info media.

Dhevy, Ni Luh Putu \& A.A Istri Dalem Hana Yundari (Ed). (2017). Procedding 4th Indonesian Conference On Tobacco Or Health 2017. Jakarta: IAKMI

Forbes, Keliie. (2016). Vaping (Electronic Cigarette Use) The Truth. Canada:Tobacco Harm Reduction Associatione

Hajek, P., Etter, J. F., Benowitz, N., Eissenberg, T., \& McRobbie, $\mathrm{H}$. (2014). Electronic cigarettes: review of use, content, safety, effects on smokers and potential for harm and benefit. Addiction, 109(11), 1801-1810.

Karuniawati, A. (2019). FaktorFaktor Yang Mempengaruhi Penggunaan Rokok Elektrik (Vape) Pada Siswa Smp Negeri Se-Kecamatan Rembang Kabupaten

Purbalingga (Doctoral dissertation, UNNES).

Kemkes. (2014). Bahaya Electronic Cigarette. Diunduh tanggal 26 Januari 2018 dari www.depkes.go.id

Ladesvita, F., \& Agustina, E. (2017).

Faktor-faktor

Mempengaruhi yang

Mengkonsumsi Rokok Elektrik (Vape) di Wilayah Jakarta Utara. Jurnal Akademi
Keperawatan Husada Karya Jaya, 3(2).

National Institute on Drug Abuse (NIH). (2018). Drug Facts: Electronic cigarettes (ECigarettes). www.drugabuse.gov

Pencegahan dan Pengendalian Penyakit Tidak Menular (P2PTM). (2017). Hidup Sehat Tanpa Rokok. Jakarta: Kemkes RI

Puterikami, A. Motivasi Penggunaan Rokok Elektrik pada Dewasa Muda di Jabodetabek Tahun 2018 (Bachelor's thesis, UIN Syarif Hidayatullah Jakarta-FK).

Noor, R. V., Mariskha, S. E., \& Umaroh, S. K. (2020). GAMBARAN POLA ASUH ORANG TUA PADA REMAJA PEROKOK DITINJAU DARI TEORI DIANA BAUMRIND. MOTIVASI, 7(1), 94-102.

Sugiyono. (2018). Metode penelitian kuantitatif, kualitatif dan R\&D. Penerbitan Alfabeta. Bandung

Sugiyono. (2015). Statistika Untuk Penelitian. Bandung: Alfa Beta

Tanuwihardja, R. K., \& Susanto, A. D. (2012). Rokok Elektronik (Electronic Cigarette). Jurnal Respirasi Indonesia, 32(1), 5361.

World Health Organization. (2019). Regional Office for South-East Asia. Global Youth Tobacco Survey (GYTS): Indonesia report, 2014. New Delhi: WHOSEARO; 2015. 